\title{
Article \\ Chain Propagation Mechanism of Fischer-Tropsch Synthesis: Experimental Evidence by Aldehyde, Alcohol and Alkene Addition
}

\author{
Liping Zhou ${ }^{1, *}$, Junhu Gao ${ }^{1}$, Xu Hao ${ }^{1,2}$, Yong Yang ${ }^{1,2}$ and Yongwang Li ${ }^{1,2}$ \\ 1 National Energy Center for Coal to Liquids, Synfuels China Technology Co., Ltd., Huairou District, \\ Beijing 101400, China; gaojunhu@synfuelschina.com.cn (J.G.); haoxu@sxicc.ac.cn (X.H.); \\ yyong@sxicc.ac.cn (Y.Y.); ywl@sxicc.ac.cn (Y.L.) \\ 2 State Key Laboratory of Coal Conversion, Institute of Coal Chemistry, Chinese Academy of Sciences, \\ Taiyuan 030001, China \\ * Correspondence: zhouliping@synfuelschina.com.cn
}

check for updates

Citation: Zhou, L.; Gao, J.; Hao, X.; Yang, Y.; Li, Y. Chain Propagation Mechanism of Fischer-Tropsch Synthesis: Experimental Evidence by Aldehyde, Alcohol and Alkene Addition. Reactions 2021, 2, 161-174 https://doi.org/10.3390/reactions 2020012

Academic Editors: Wenping Ma, Ajay K. Dalai and Dmitry Yu. Murzin

Received: 26 April 2021

Accepted: 31 May 2021

Published: 8 June 2021

Publisher's Note: MDPI stays neutral with regard to jurisdictional claims in published maps and institutional affiliations.

Copyright: (c) 2021 by the authors. Licensee MDPI, Basel, Switzerland. This article is an open access article distributed under the terms and conditions of the Creative Commons Attribution (CC BY) license (https:/ / creativecommons.org/licenses/by/ $4.0 /)$.

\begin{abstract}
Fischer-Tropsch synthesis (FTS) produces hundreds of hydrocarbons and oxygenates by simple reactants $\left(\mathrm{CO}+\mathrm{H}_{2}\right)$ and the detailed chain propagation mechanism is still in dispute. An industrial iron-based catalyst was used to further clarify the mechanism by adding aldehyde, alcohol and alkene species into a fixed-bed tubular reactor. The added species were investigated in $\mathrm{H}_{2}$ and syngas atmospheres, respectively. 1-alkene in the $\mathrm{H}_{2}$ atmosphere presented an obvious hydrogenolysis, in which the produced $\mathrm{C}_{1}$ species participated in $\mathrm{C}-\mathrm{C}$ bond formation simultaneously. Co-feeding $C_{n}$ alkene with syngas showed remarkable $C_{n+1}$ alcohol selectivity compared to the normal FTS reaction. In addition, the carbonyl group of aldehyde was extremely unstable over the iron-based catalyst and could easily be hydrogenated to an alcohol hydroxyl group, which could even undergo dehydration for hydrocarbon species formation. Experimental data confirmed that both heavier alkenes and alcohols added can be converted to chain growth intermediates and then undergo monomer insertion for chain propagation. These results provide strong evidence that the chain propagation in the FTS reaction is simultaneously controlled by the surface carbide mechanism and the $\mathrm{CO}$ insertion mechanism, with surface $\mathrm{CH}_{x}$ species and $\mathrm{CO}$ as monomers, respectively. The study is of guiding significance for FTS mechanism understanding and kinetic modeling.
\end{abstract}

Keywords: Fischer-Tropsch; mechanism; alkene; alcohol; aldehyde; chain propagation factor; product distribution

\section{Introduction}

Fischer-Tropsch synthesis (FTS) has attracted extensive attention because it is a feasible technology for the conversion of coal, biomass and natural gas (via gasification or steam reforming to syngas) into liquid fuels [1,2]. However, the fundamental understanding of the chain growth mechanism is still a developing field. Much work has been devoted to this aspect in numerous laboratories from almost as early as the 1920s. In general, three independent chain growth assumptions have been proposed (summarized in Scheme 1): the surface carbide mechanism [3], the CO insertion mechanism [4] and the surface enol mechanism [5].

The surface carbide mechanism (Scheme 1a) implies that FTS chain propagation is performed by oxygen-eliminated monomers $\left(\mathrm{CH}_{x}\right.$, formed by direct or $\mathrm{H}$-assisted $\mathrm{CO}$ dissociation [6-9]) and the chain terminates for linear alkane and alkene formation by hydrogenation or $\beta$-hydride elimination of the intermediates. Hydrogen could react either in a molecular state or by dissociative adsorption, but here we have emphasized the dissociative adsorption in Scheme 1 because hydrogen dissociation has a low activation barrier [10] and the related kinetic model could predict experimental data accurately over a wide range of reaction conditions [11]. Direct evidence to support this mechanism was the $\mathrm{CH}_{2} \mathrm{~N}_{2} / \mathrm{H}_{2}$ 
experiment determined by Brady and Pettit [12], in which a remarkable polymerization of $\mathrm{CH}_{2}$ groups into high carbon-number hydrocarbons was presented over iron, cobalt and ruthenium metals $\left(\mathrm{CH}_{2} \mathrm{~N}_{2}\right.$ could be rapidly decomposed over these metals at 1 atmosphere and $298-473 \mathrm{~K}$ for $\mathrm{CH}_{2}$ species formation and then undergo chain propagation). Other reasonable evidence includes the addition of $\mathrm{CH}_{2}$ related probes $[13,14]$ and $\mathrm{CH}_{2}$ trap experiments with reactions of addition to unsaturated compounds such as cyclohexene and benzene $[15,16]$. The surface carbide mechanism is widely used in elementary step assumption, kinetic modeling and the explanation of hydrocarbon formation in the FTS process [17-21]. The CO insertion mechanism (Scheme $1 \mathrm{~b}$ ) assumes that $\mathrm{C}-\mathrm{C}$ chain propagation proceeds via the insertion of $\mathrm{CO}$ monomers into surface metal- $\mathrm{H}$ (the first initiation) and the metal-carbon bond of surface hydrocarbon intermediates, a well-known reaction in homogeneous catalysis, and the terminal oxygen is ultimately eliminated by hydrogenation and/or dehydration. This mechanism has been universally recognized as the main pathway for the oxygenate formation in FTS. The surface enol mechanism (Scheme 1c) suggests a scheme of chain growth by self-condensation of hydroxycarbene monomers, generating oxygenated intermediates that exhibit as precursors for both hydrocarbon and oxygenate formation. This mechanism is mainly supported by sorption measurements suggesting enolic complexes $\mathrm{M}=\mathrm{CH}(\mathrm{OH})$ [22]. However, no experimental results have indicated that the growing chain was formed by oxygen-involved species through the self-condensation process. In fact, the $\mathrm{C}-\mathrm{C}$ bond formation between hydroxycarbene electrophilic species is not very common.

(a) surface carbide mechanism
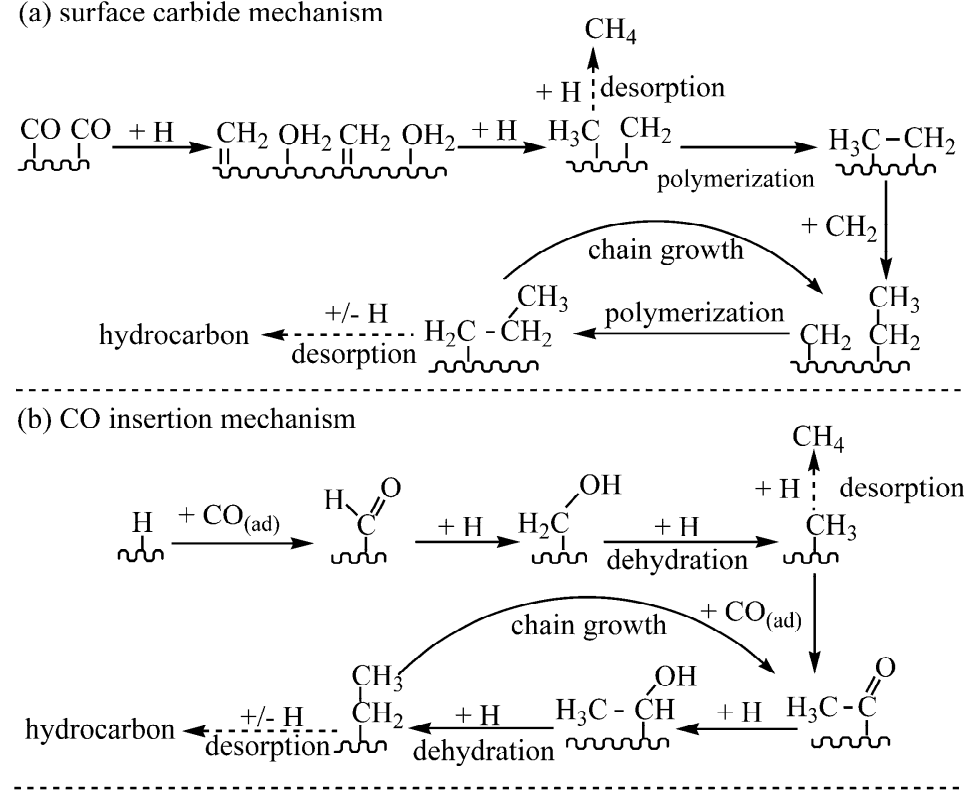

(c) surface enol mechanism

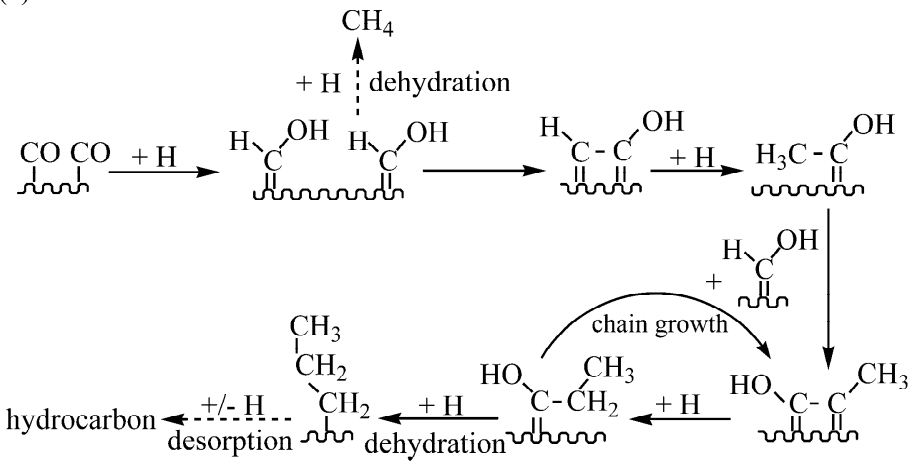

Scheme 1. The three prevalent chain growth mechanisms in FTS reaction. (a) surface carbide mechanism. (b) CO insertion mechanism. (c) surface enol mechanism. 
The product spectrum of FTS consists of a very broad range of hydrocarbons (mainly linear paraffin and olefin) and oxygenates (mainly alcohol, small amounts of acids, aldehydes, ketones and esters), with carbon numbers from $C_{1}$ to as high as $C_{120+}$. An AndersonSchulz-Flory (ASF) equation, with one chain propagation factor $\alpha$, is normally used to describe this product distribution [23]:

$$
\begin{gathered}
\mathrm{m}_{n}=(1-\alpha) \alpha^{\mathrm{n}-1} \\
\alpha=R_{\mathrm{p}} /\left(R_{\mathrm{p}}+R_{\mathrm{t}}\right)
\end{gathered}
$$

where $\alpha$ is the chain propagation factor, $\mathrm{n}$ is the carbon number, $\mathrm{m}_{n}$ is the molar fraction of the $C_{\mathrm{n}}$ hydrocarbon, and $R_{\mathrm{p}}$ and $R_{\mathrm{t}}$ are the rates of chain propagation and termination, respectively. However, in most cases the real FTS product selectivity does not obey this ideal distribution, but shows a two- $\alpha$ distribution [24] with a carbon number. The extent of the deviation from ASF distribution varies with the operating conditions (temperature, pressure, space velocity, $\mathrm{H}_{2} / \mathrm{CO}$ ratio and reaction environment) and catalyst promoters [21,24-29].

In fact, none of the elementary-step-level kinetic models based on a mechanism mentioned above can predict the whole product distribution observed in the FTS reaction independently. Currently, the most prevalent explanation of this deviation is the readsorption and secondary chain growth of primary product alkenes. It is proposed that the residence time of long-chain alkenes is increased because of physical adsorption, diffusion or solubility influences, which enhances their chances of undergoing a secondary reaction and leads to increased chain growth factor $\alpha$ with increasing chain length of alkenes $[21,25,30,31]$. Another explanation for this deviation is the two-mechanism assumption. Gaube and co-workers proposed that the superimposed distributions were the result of different catalytic sites causing different chain growth mechanisms, especially over the alkali promoter catalysts [28,32]. This two-site mechanism was also supported by Huff and Satterfield [24] and Davis et al. [33].

Probe co-feeding studies such as light alkenes (mainly $\mathrm{C}_{2}-\mathrm{C}_{4}$ alkenes) [34-42], heavy alkenes [40,43-45], alcohols [5,40,46-49] and aldehydes [34] were reported to investigate the chain growth mechanism and the secondary reaction of the components. In all these cases, hydrogenation of the probe molecule to its corresponding alkane was the main reaction. Most of the studies concluded that the added alkenes or alcohols can be incorporated into growing hydrocarbon chains by initiating chain growth. However, the possible chain propagation routes that simultaneously occur in the real FTS process are still not very clear. We believe that the FTS reaction mechanism could be further clarified by more co-feeding experiments in various reaction conditions.

The continuing argument on the subject prompted us to further investigate the FTS reaction mechanism over a typical iron-based catalyst. In the present work we mainly focused on the analysis of the reaction behavior of aldehyde, alcohol and alkene (extending the carbon number to $\mathrm{C}_{8}$ ) and the discrimination of chain growth mechanisms in FTS. The experiments were performed in an inert Ar atmosphere, an $\mathrm{H}_{2}$ atmosphere and a syngas atmosphere, respectively. The results herein provide some interesting information for a better understanding of FTS chain propagation.

\section{Materials and Methods}

\subsection{Materials}

The liquid reactants, oxygenates $\left(C_{1}-C_{3}\right.$ alcohols, $99.7 \% ; C_{5}$ and $C_{6}$ alcohols, $98.5 \%$; propionaldehyde, $98.0 \%$ ) and 1-alkenes (1-Hexene, $98.0 \%$; 1-Octene, $97 \%$ ), were measured and fed by a piston mini-pump, Beijing Xingda Science and Technology Development Co., Ltd, Beijing, China. The gas reactants $\left(\mathrm{CO}, \mathrm{H}_{2}, \mathrm{C}_{2} \mathrm{H}_{4}\right.$ and $\left.\mathrm{C}_{3} \mathrm{H}_{6}, 99.99 \%\right)$ were measured by Brooks 5850E mass flow controllers, Hatfield, PA, USA. The proprietary, industrial ironbased catalyst used in this mechanism study was prepared by Synfuels China Technology Co., Ltd., Beijing, China. [50]. 


\subsection{Methods}

The experiments were carried out in a fixed-bed tubular reactor (Figure 1, steel tube with $30 \mathrm{~cm} \times 8 \mathrm{~mm}$ i.d.), which was loaded with $0.5 \mathrm{~g}$ of fresh catalyst (diameter, $0.150-0.180 \mathrm{~mm}$ ) diluted with $1.0 \mathrm{~g} \mathrm{SiC}$. Quartz wool was placed at the bottom of the reactor to support the catalyst mixture. A thermowell located in the center of the reactor and a thermocouple were used to monitor the real reaction temperature. An electric heating device maintained a constant temperature $(483 \mathrm{~K})$ for the lines from the outlet of the reactor to the inlet of the gas chromatograph (GC, Agilent 7890N (Agilent Technologies, Santa Clara, CA, USA) with four columns: 1 DB-Petro capillary,1 PropakQ, 1 CarbonPLOT capillary and 1 MoleSieve 5A capillary, oven temperature was $573.15 \mathrm{~K}$ ), achieving online GC analysis of the whole product stream within our experimental conditions (TCD: CO, $\mathrm{H}_{2}, \mathrm{CO}_{2}, \mathrm{Ar}, \mathrm{C}_{1}-\mathrm{C}_{3}$ hydrocarbons; FID: hydrocarbons and oxygenates). In each set of the experiments, the fresh catalyst was reduced by syngas at a specified condition. Next, the catalyst underwent steady-state transition at a constant condition $\left(\mathrm{T}, 533 \mathrm{~K} ; \mathrm{P}_{\text {total }}\right.$, $0.8 \mathrm{MPa} ; \mathrm{H}_{2} / \mathrm{CO}, 1.6$; space velocity, $10,000 \mathrm{~mL} \mathrm{~g}^{-1} \mathrm{~h}^{-1}$ ) for about $50 \mathrm{~h}$, then the catalyst was flushed for $5 \mathrm{~h}$ by switching the syngas into inert Ar (high purity, 99.99\%). Subsequently, the mechanism studies were carried out at $533 \mathrm{~K}$ and $0.8-1.0 \mathrm{MPa}$ with a space velocity of 10,000-11,000 $\mathrm{mL} \mathrm{g}^{-1} \mathrm{~h}^{-1}$. Ar was added and served as an internal standard for the purpose of data processing.

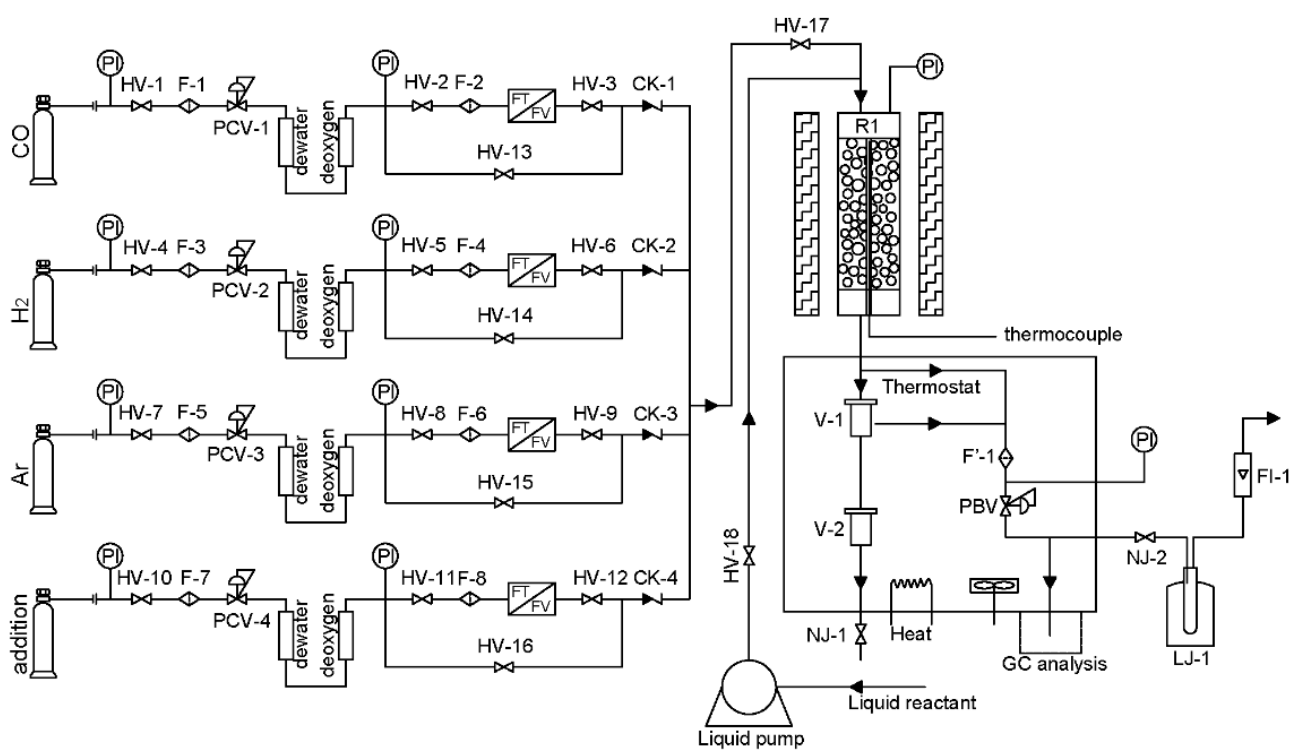

Figure 1. Schematic apparatus of the fixed-bed reactor for FTS mechanism experiments (HV, globe valves; F, filter; $\mathrm{CK}$, non-return valves; $\mathrm{PCV}$, pressure reducing valves; $\mathrm{F}^{\prime}$, thermal resistant filter; $\mathrm{NJ}$, thermal resistant globe valves; R1, fixed-bed reactor; PBV, back-pressure regulator; LJ, cold trap; FI, flow meter; $\mathrm{V}$, gas-liquid separator).

\section{Results and Discussion}

\subsection{Mechanism Investigation with 1-Alkene as Single Carbon Source}

In an inert Ar atmosphere, GC analysis of the reactor effluent did not find any other response except for the alkene probe itself in single alkene feeding. This indicates that a single alkene can hardly be activated for any surface reaction at typical FTS reaction conditions over the reduced iron-based catalyst.

However, the reactivities of alkenes are highly increased in an $\mathrm{H}_{2}$ atmosphere (Table 1). When the inlet was switched from $\mathrm{H}_{2}$ to mixed $\mathrm{C}_{2} \mathrm{H}_{4}$ and $\mathrm{H}_{2}\left(\mathrm{H}_{2} / \mathrm{C}_{2} \mathrm{H}_{4}=10.0\right)$ over the reduced catalyst, the production rate of $\mathrm{CH}_{4}$ was increased by nearly 16 times (single $\mathrm{H}_{2}$ atmosphere: $\mathrm{CH}_{4}$ produced by the hydrogenation of $\mathrm{FeCx}$ formed in the catalyst reduction process). This phenomenon can surely be attributed to the $\mathrm{C}-\mathrm{C}$ bond cleavage of the activated $\mathrm{C}_{2} \mathrm{H}_{4}$ reactant and the consequent hydrogenation of the $\mathrm{C}_{1}$ species. In 
addition, we observed a part of the chain propagation $\left(\mathrm{C}_{3+}\right.$ about $\left.1.3 \%\right)$ although the proportion of direct hydrogenation for $\mathrm{C}_{2} \mathrm{H}_{6}$ was extremely high at this $\mathrm{H}_{2} / \mathrm{C}_{2} \mathrm{H}_{4}$ condition. The proportion of chain propagation was increased from 1.3 to $6.6 \%$ (Table 1 ) when continuously decreasing the $\mathrm{H}_{2} / \mathrm{C}_{2} \mathrm{H}_{4}$ ratio from 10 to 2 .

Table 1. $\mathrm{C}_{2} \mathrm{H}_{4}$ reaction in $\mathrm{H}_{2}$ atmosphere $(\mathrm{T}=533 \mathrm{~K}, p=0.8 \mathrm{MPa})$.

\begin{tabular}{ccccc}
\hline \multirow{2}{*}{$\begin{array}{c}\text { Product Selectivity } \\
(\mathbf{m o l} \%)\end{array}$} & $\mathbf{2}$ & $\mathbf{4}$ & $\mathbf{H}_{\mathbf{2}} / \mathbf{C}_{\mathbf{2}} \mathbf{H}_{\mathbf{4}}$ \\
\cline { 2 - 5 } & 1.4 & 2.0 & $\mathbf{5}$ & $\mathbf{1 0}$ \\
\hline $\mathrm{CH}_{4}$ & 7.1 & - & 2.0 & 1.5 \\
$\mathrm{C}_{2} \mathrm{H}_{4}$ & 84.9 & 93.8 & - & - \\
$\mathrm{C}_{2} \mathrm{H}_{6}$ & 6.6 & 4.2 & 2.9 & 97.2 \\
$\mathrm{C}_{3+}$ & & & \\
\hline
\end{tabular}

Similar results were obtained in the $\mathrm{C}_{3} \mathrm{H}_{6}$ reaction, in which the reactant was fully converted even at a low $\mathrm{H}_{2} / \mathrm{C}_{3} \mathrm{H}_{6}$ ratio (Table 2). Except for the main reaction route for $\mathrm{C}_{3} \mathrm{H}_{8}$ formation, the hydrogenolytic cleavage $\left(\mathrm{CH}_{4}\right.$ and $\mathrm{C}_{2}$ products) and chain growth $\left(\mathrm{C}_{4+}\right.$ selectivity) were also observed simultaneously. Both chain propagations obey the ASF theory, in which a $\mathrm{C}_{2} \mathrm{H}_{4}$ reaction is obtained from a $\mathrm{C}_{3}$ hydrocarbon (Figure 2a) and a $\mathrm{C}_{3} \mathrm{H}_{6}$ reaction is obtained from $\mathrm{C}_{4}$ hydrocarbon (Figure $2 \mathrm{~b}$ ), respectively.

Table 2. $\mathrm{C}_{3} \mathrm{H}_{6}$ reaction in $\mathrm{H}_{2}$ atmosphere $(\mathrm{T}=533 \mathrm{~K}, p=0.8 \mathrm{MPa})$.

\begin{tabular}{cccc}
\hline $\begin{array}{c}\text { Product Selectivity } \\
(\mathbf{m o l} \%)\end{array}$ & \multicolumn{3}{c}{$\mathbf{H}_{\mathbf{2}} / \mathbf{C}_{\mathbf{3}} \mathbf{H}_{\mathbf{6}}$} \\
\cline { 2 - 4 } & $\mathbf{3}$ & $\mathbf{7}$ & $\mathbf{1 1}$ \\
\hline $\mathrm{CH}_{4}$ & 2.0 & 3.0 & 3.6 \\
$\mathrm{C}_{2} \mathrm{H}_{4}+\mathrm{C}_{2} \mathrm{H}_{6}$ & 3.0 & 3.4 & 3.6 \\
$\mathrm{C}_{3} \mathrm{H}_{6}$ & - & - & - \\
$\mathrm{C}_{3} \mathrm{H}_{8}$ & 89.3 & 90.3 & 90.5 \\
$\mathrm{C}_{4+}$ & 5.7 & 3.3 & 2.3 \\
\hline
\end{tabular}
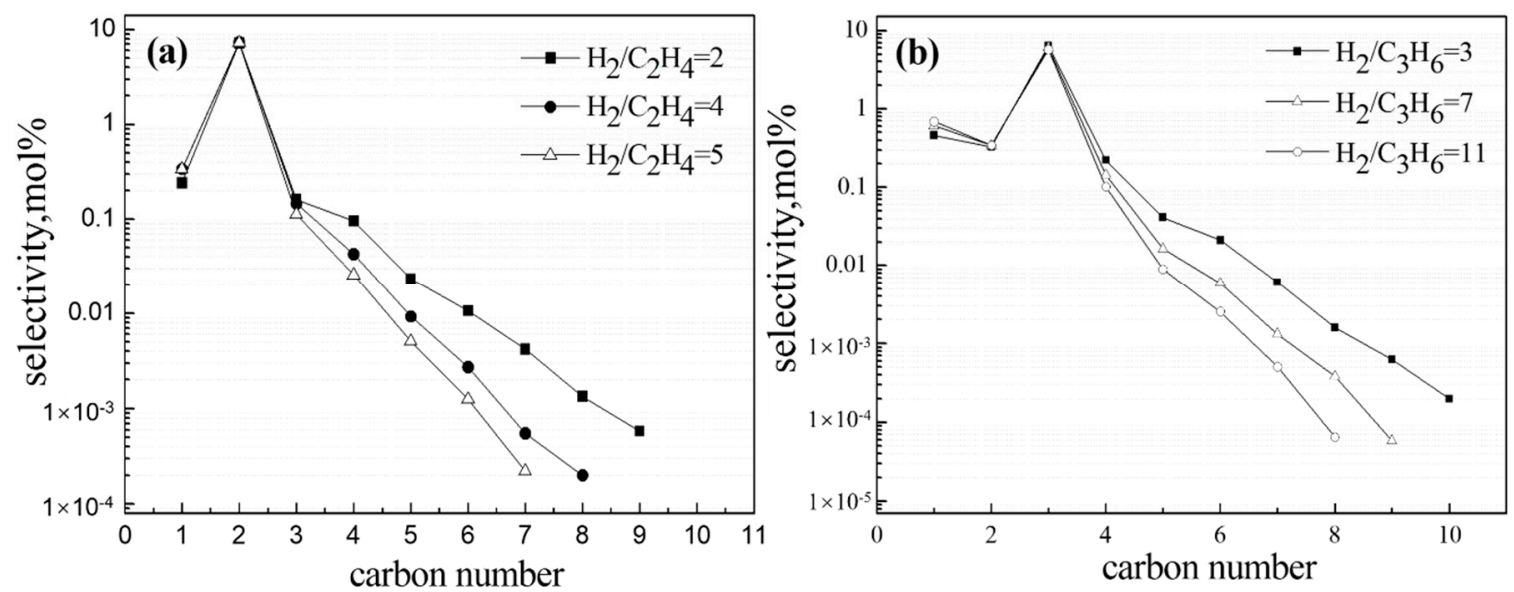

Figure 2. The product distribution of the light alkene reaction $(\mathrm{T}=533 \mathrm{~K}, p=0.8 \mathrm{MPa})$. (a) $\mathrm{C}_{2} \mathrm{H}_{4}$ in $\mathrm{H}_{2}$ atmosphere. (b) $\mathrm{C}_{3} \mathrm{H}_{6}$ in $\mathrm{H}_{2}$ atmosphere.

The heavier 1-alkenes, such as $\mathrm{C}_{6} \mathrm{H}_{12}$ and $\mathrm{C}_{8} \mathrm{H}_{16}$, also showed high reactivities. The conversions of $\mathrm{C}_{6}$ and $\mathrm{C}_{8}$ alkenes were 84.7 and $98.0 \%$, respectively, when the inlet $\mathrm{H}_{2} / \mathrm{C}_{\mathrm{n}} \mathrm{H}_{2 n}$ ratio was 2:1. They can be almost entirely converted if the inlet ratio is increased to 5:1 (Table 3). The selectivity of the corresponding n-alkane by direct hydrogenation of the heavier 1-alkene was remarkably low as compared to that of the light alkene reactions (such as $C_{2}$ and $C_{3}$ alkenes) although it was still very sensitive to the increase 
of $\mathrm{H}_{2}$ pressure. Instead, 1-alkene isomerization by a double bond shift from the terminal position to the internal position was significantly increased (Table 3). This phenomenon is in agreement with the metal hydride addition-elimination mechanism, which was also supported by Cramer and Shi et al. [51,52] to explain the isomerization of 1-alkene, as depicted in Scheme 2.

Table 3. Reactions of $\mathrm{C}_{6} \mathrm{H}_{12}$ and $\mathrm{C}_{8} \mathrm{H}_{16}$ in $\mathrm{H}_{2}$ atmosphere $(\mathrm{T}=533 \mathrm{~K}, p=0.8 \mathrm{MPa})$.

\begin{tabular}{|c|c|c|c|c|}
\hline \multirow{2}{*}{$\begin{array}{l}\text { Product Selectivity } \\
\text { (mol\%) }\end{array}$} & \multicolumn{2}{|c|}{$\mathrm{H}_{2} / \mathrm{C}_{6} \mathrm{H}_{12}$} & \multicolumn{2}{|c|}{$\mathrm{H}_{2} / \mathrm{C}_{8} \mathrm{H}_{16}$} \\
\hline & $2.1(X=84.7 \%)^{a}$ & $5.1(X=98.6 \%)$ & $2.1(X=98.0 \%)$ & $5.1(X=99.4 \%)$ \\
\hline methane & 1.2 & 2.4 & 0.9 & 2.6 \\
\hline 2-alkene ${ }^{b}$ & 56.4 & 41.1 & 50.9 & 23.9 \\
\hline n-alkane & 35.5 & 51.6 & 43.2 & 66.5 \\
\hline Others & 6.9 & 4.9 & 5.0 & 7.0 \\
\hline
\end{tabular}

a $\mathrm{X}$ in the parentheses indicates the conversion of $\mathrm{C}_{6} \mathrm{H}_{12}$ or $\mathrm{C}_{8} \mathrm{H}_{16}$ at the corresponding reaction condition;

b 2-alkene includes cis and trans structures.

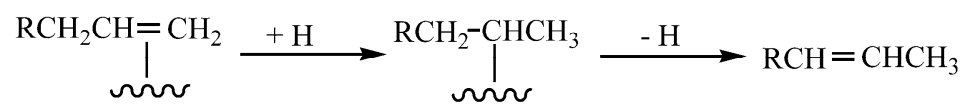

Scheme 2. Isomerization of 1-alkene for 2-alkene formation.

The detailed product distributions in these heavier 1-alkene reactions presented some extremely interesting patterns. On one hand, parts of the activated $C_{6}$ and $C_{8}$ alkenes have undergone terminal $\mathrm{C}-\mathrm{C}$ bond cleavage step by step for methane and other light hydrocarbon formations (from p1 to p3 in Figure 3); on the other hand, the alkenes could initiate chain propagation by polymerizing a $\mathrm{C}_{1}$ monomer, and the product plots obeyed an ASF distribution from point p4 in Figure 3. Simultaneously, the section from $\mathrm{p} 3$ to $\mathrm{p} 2$ by $C_{1}$ species initiating chain propagation also obeyed the ASF distribution (from $C_{1}$ to $C_{3}$ hydrocarbons, Figure 3a).
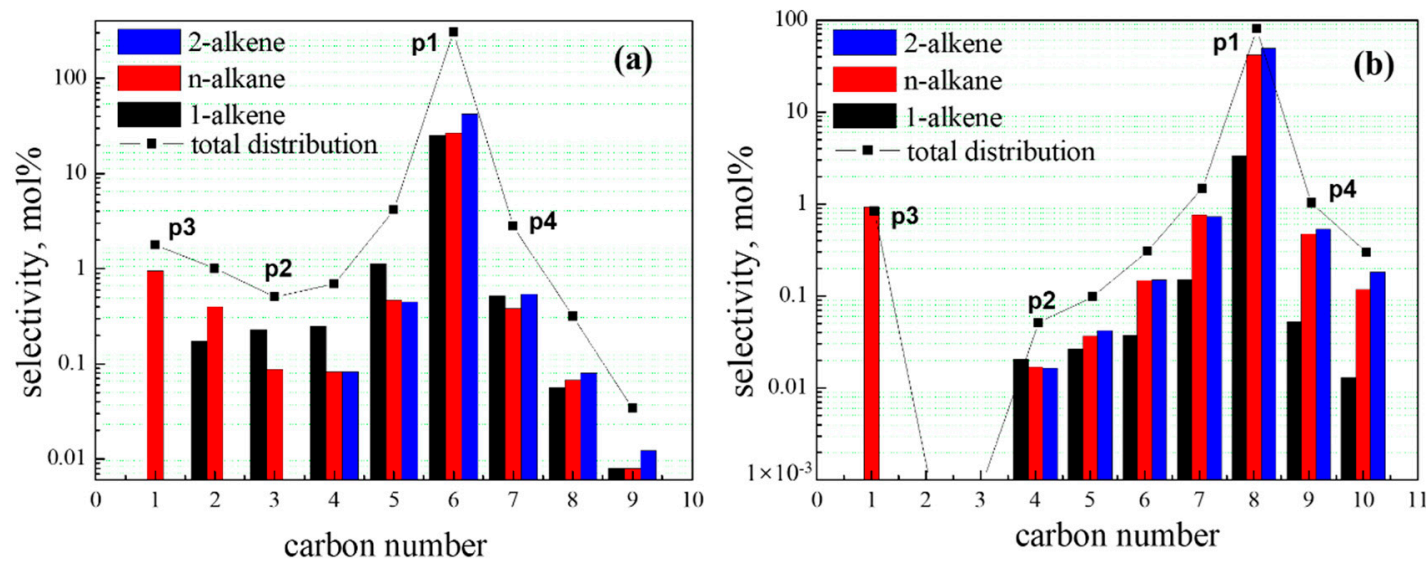

Figure 3. The detailed product distribution of heavier 1-alkene reaction ( $\mathrm{T}=533 \mathrm{~K}, p=0.8 \mathrm{MPa})$. (a) $\mathrm{C}_{6} \mathrm{H}_{12}$ in $\mathrm{H}_{2}$ atmosphere, $\mathrm{H}_{2} / \mathrm{C}_{6} \mathrm{H}_{12}=$ 2.1. (b) $\mathrm{C}_{8} \mathrm{H}_{16}$ in $\mathrm{H}_{2}$ atmosphere, $\mathrm{H}_{2} / \mathrm{C}_{8} \mathrm{H}_{16}=2.1$.

Therefore, these experimental results from using 1-alkene as a single carbon source clearly exhibit hydrogenation, isomerization, hydrogenolysis and $\mathrm{C}-\mathrm{C}$ chain growth reactions. Hydrogenation and isomerization account for most of the total conversion under this condition. However, the most important thing is that our results present an extremely good relationship between $\mathrm{C}-\mathrm{C}$ bond cleavage and $\mathrm{C}-\mathrm{C}$ bond formation over the reduced catalyst, which can be described in Scheme 3 . 


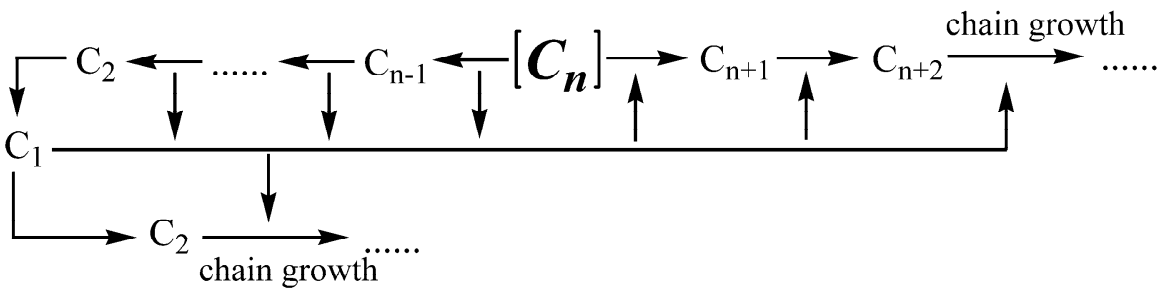

Scheme 3. Hydrogennolysis for $C_{1}$ monomer formation and chain growth by surface carbide mechanism.

The essential significance of the above results is that polymerization of $C_{1}$ monomers (originated from $\mathrm{C}-\mathrm{C}$ bond cleavage of 1-alkene) step by step is feasible over the iron-based catalyst, and the chain intermediates are unlikely to be propagated by $\mathrm{C}_{2+}$ species (that means no remarkable $C_{2+}$ species served as monomers) since no obvious saw-toothed distributions were observed. These experiments further reinforce the surface carbide mechanism over an iron-based catalyst. By combining with the measured surface rich in $\mathrm{CH}_{x}$ species in the adsorption of the syngas [53-55], we confirmed that at least some of the FTS hydrocarbon products originated from the polymerization of the oxygen-eliminated $\mathrm{CH}_{x}$ species.

\subsection{Alcohol Selectivity by Co-Feeding 1-Alkene in Normal FTS Reaction}

By comparing with the non-addition experiments, we found that the addition of $C_{n}$ alkene to syngas caused a remarkable increase of the selectivity of $\mathrm{C}_{n+1}$ alcohol (e.g., $\mathrm{C}_{2} \mathrm{H}_{4}$, $\mathrm{C}_{3} \mathrm{H}_{6}$ and $\mathrm{C}_{6} \mathrm{H}_{12}$ addition in Figure 4), which returned to the normal selectivity once the addition of these alkenes was terminated. The selectivity of $C_{n+1}$ alcohol was directly proportional to the increase in the partial pressure of $C_{n}$ alkene, e.g., the selectivity of n-propanol and n-butanol depicted in Figure 5. In fact, similar results were discovered by Otto Roelen [56] in early 1938 with ethylene addition (named the Roelen reaction, hydroformylation or Oxo synthesis). This hydroformylation reaction was always used to explain the oxygenate formation, but it attracted relatively little attention in respect of the FTS reaction until quite recently since the selectivity of alcohol products is very low compared to that of the hydrocarbon products. However, here we emphasize that the hydroformylation reaction could be regarded as the first step of the CO insertion mechanism as exhibited in Scheme $1 \mathrm{~b}$. During the $C_{n}$ alkene co-feeding process, the surface concentration of the $C_{n}$ intermediate was largely increased. Subsequently, the adsorbed $\mathrm{CO}$ species was inserted into the $\mathrm{C}_{\mathrm{n}}$ intermediate and underwent further hydrogenation and desorption for $\mathrm{C}_{\mathrm{n}+1}$ alcohol formation.

One question is whether these oxygen-involved intermediates could be further hydrogenated and dehydrated for hydrocarbon intermediate formation over an iron-based catalyst. This step is crucial for an integrated assumption of the CO insertion mechanism as presented in Scheme 1b. An experimental investigation was performed and is discussed in the following section. 


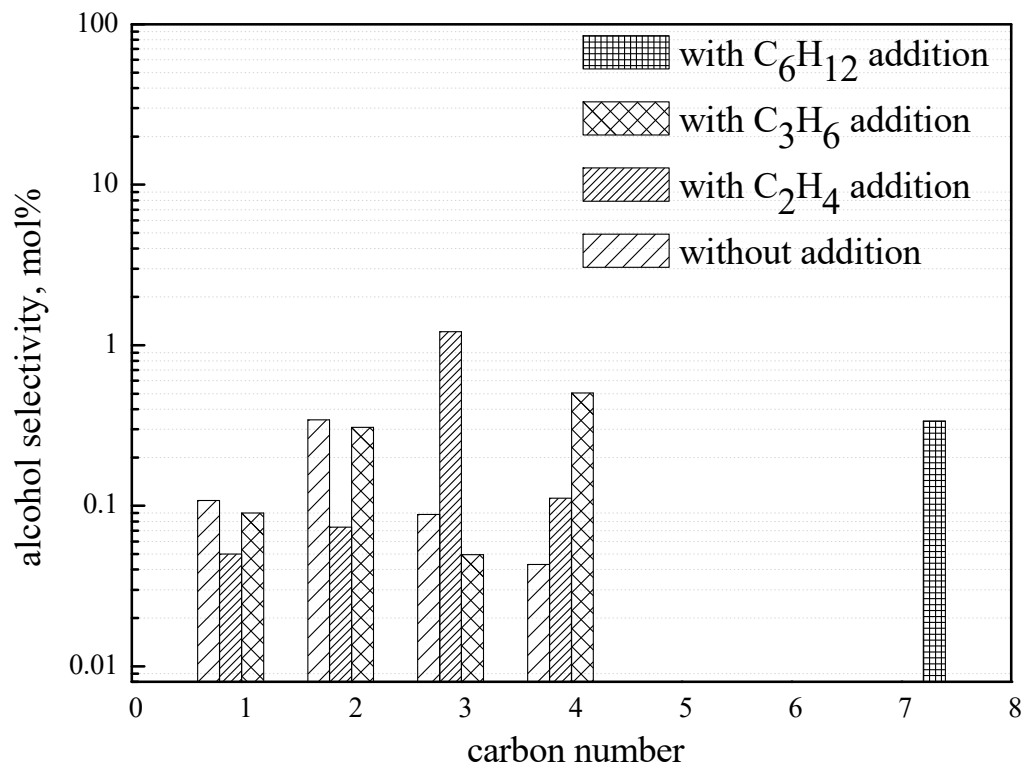

Figure 4. Effects of alkene addition on alcohol selectivity $\left(\mathrm{T}=533 \mathrm{~K}, p=0.8 \mathrm{Mpa}, \mathrm{H}_{2} / \mathrm{CO}=12.0\right.$, among the addition: $\mathrm{H}_{2} / \mathrm{C}_{2} \mathrm{H}_{4}=4.0, \mathrm{H}_{2} / \mathrm{C}_{3} \mathrm{H}_{6}=4.1, \mathrm{H}_{2} / \mathrm{C}_{6} \mathrm{H}_{12}=2.6$ ).
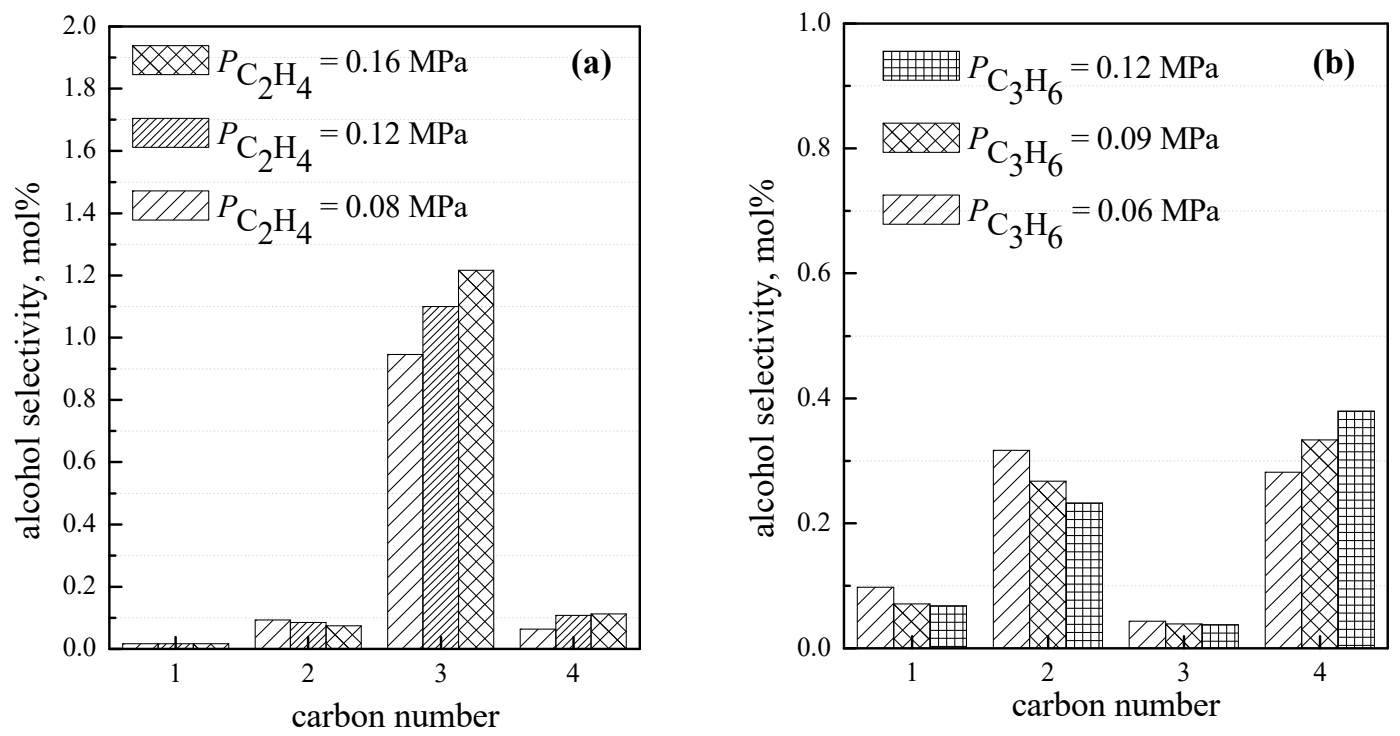

Figure 5. The alcohol selectivity with the increase in alkene partial pressure $\left(\mathrm{T}=533 \mathrm{~K}, p=0.8 \mathrm{Mpa}, \mathrm{H}_{2} / \mathrm{CO}=12.0\right)$. (a) $\mathrm{C}_{2} \mathrm{H}_{4}$ addition. (b) $\mathrm{C}_{3} \mathrm{H}_{6}$ addition.

\subsection{Mechanism Investigation with Aldehyde or Alcohol as Single Carbon Source}

Taking propionaldehyde $\left(\mathrm{CH}_{3} \mathrm{CH}_{2} \mathrm{CHO}\right.$, inlet $\left.0.5 \mathrm{~mL} / \mathrm{h}\right)$ as an example, the results (Table 4) clearly show that the carbonyl bond of aldehyde can easily be hydrogenated over the iron-based FTS catalyst. It was almost totally converted at $\mathrm{H}_{2} / \mathrm{C}_{3} \mathrm{H}_{6} \mathrm{O}=21.75$. This is consistent with the realistic product distribution of the FTS reaction in which the selectivity of the aldehyde is extremely low. Except for the most part of propanol selectivity, we found that a small number of hydrocarbon products, mainly $\mathrm{C}_{2}-\mathrm{C}_{4}$ hydrocarbons, were formed during the hydrogenation of propionaldehyde. This can be attributed to the further hydrogenation of the formed alcohol hydroxyl groups and their dehydration. The aldehyde is most likely an intermediate product in the CO insertion mechanism. 
Table 4. The hydrogenation and dehydration results for the propionaldehyde reaction.

\begin{tabular}{cccccc}
\hline \multirow{2}{*}{$\begin{array}{c}\text { Reaction Results } \\
(\mathbf{m o l} \%)\end{array}$} & $\mathbf{2 . 8 3}$ & $\mathbf{4 . 3 8}$ & $\mathbf{7 . 9 6}$ & $\mathbf{1 1 . 8 8}$ & $\mathbf{2 1 . 7 5}$ \\
\cline { 2 - 5 } & 66.19 & 86.52 & 97.51 & 98.16 & 99.15 \\
\hline $\begin{array}{c}\text { Conversion, } \mathrm{C}_{3} \mathrm{H}_{6} \mathrm{O} \% \\
\text { Selectivity, propanol\% }\end{array}$ & 93.30 & 94.45 & 95.39 & 95.84 & 96.45 \\
$\quad \begin{array}{c}\text { Selectivity, } \\
\text { hydrocarbon } \\
\left(\mathrm{C}_{2}-\mathrm{C}_{4}\right) \%\end{array}$ & 4.73 & 3.46 & 4.51 & 4.05 & 3.35 \\
\hline
\end{tabular}

We further confirmed the hydrogenation and dehydration of the alcohol hydroxyl group by adding $\mathrm{C}_{2}, \mathrm{C}_{3}, \mathrm{C}_{5}$ and $\mathrm{C}_{6}$ alcohols into an $\mathrm{H}_{2}$ atmosphere. In order to minimize the reoxidation of the metallic phases of the catalyst, the residence time of the added alcohol was largely decreased by keeping a large volume of the Ar carrier. Thus, the conversion of alcohol in our experiments was maintained below $5 \%$. Results show that the hydrogenation of $C_{n}$ alcohol mainly led to the hydrocarbon formation from $C_{n-1}$ to $C_{n+1}$, in which the corresponding $C_{n}$ hydrocarbon showed the highest selectivity (Figure 6). Previous publications suggested that the hydrogenolysis of an alcohol occurred to produce an alkane with the same carbon number but not an alkene [42,47]. Here we found that alkenes exhibited a much higher selectivity than alkanes when adding $C_{n}(n \geq 3)$ alcohol, as shown in Figure 6. Moreover, the product distributions presented here were very similar to those of the hydrogenation of the heavier 1-alkene shown in Figure 3, suggesting that the dehydrated $C_{n}$ hydrocarbon species here also underwent further $C-C$ bond cleavage and chain growth for $\mathrm{C}_{\mathrm{n}-1}$ and $\mathrm{C}_{\mathrm{n}+1}$ hydrocarbon formation, respectively.
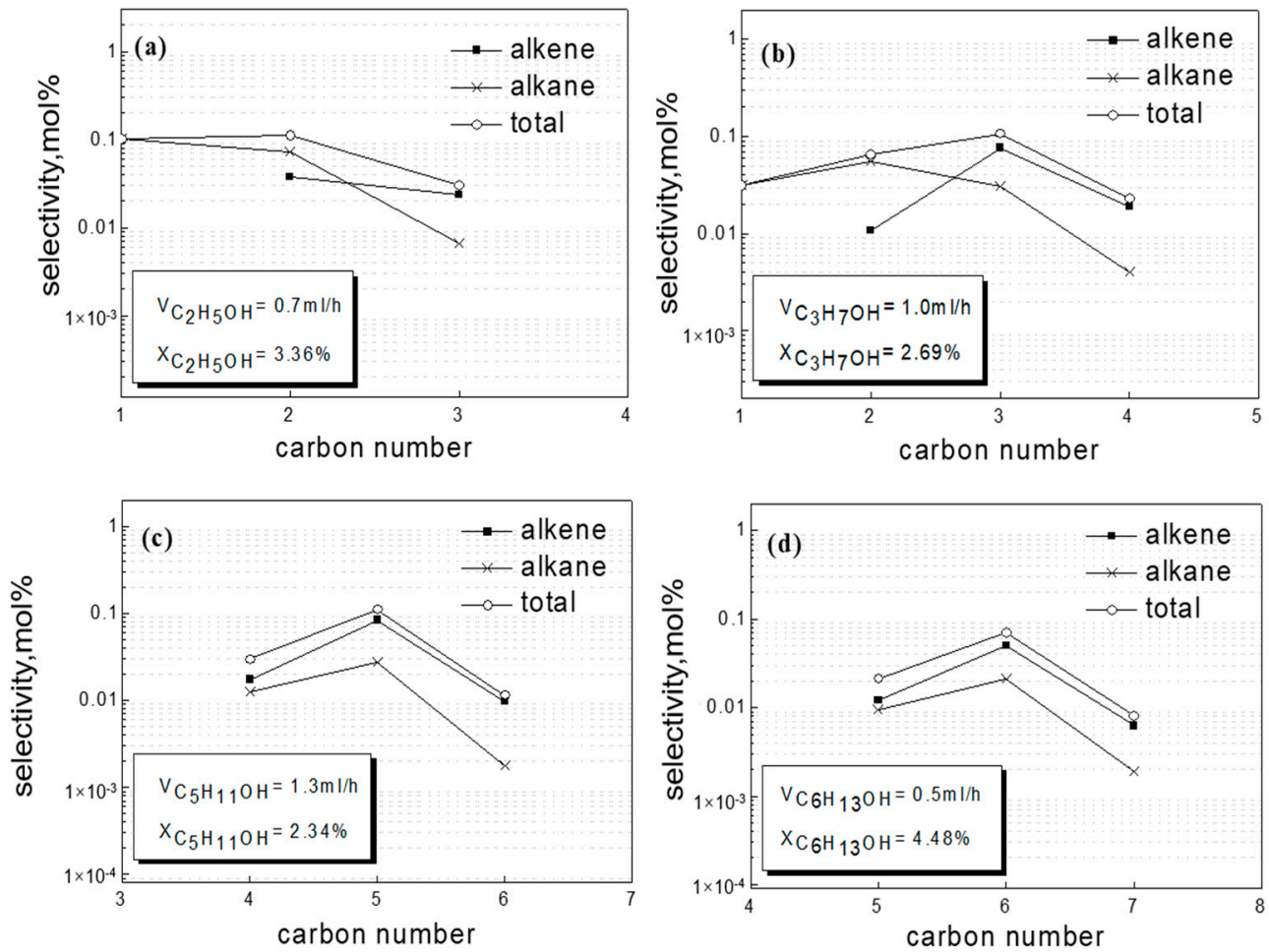

Figure 6. The dehydration of alcohols in an $\mathrm{H}_{2}$ atmosphere over a reduced iron-based catalyst ( $\mathrm{T}=533 \mathrm{~K}, p=0.8 \mathrm{Mpa}$ ). (a) $\mathrm{C}_{2} \mathrm{H}_{5} \mathrm{OH}$ addition. (b) $\mathrm{C}_{3} \mathrm{H}_{7} \mathrm{OH}$ addition. (c) $\mathrm{C}_{5} \mathrm{H}_{11} \mathrm{OH}$ addition. (d) $\mathrm{C}_{6} \mathrm{H}_{13} \mathrm{OH}$ addition.

By summarizing the experimental results shown in previous sections, we propose that the aldehyde formed in the FTS process is an intermediate product of the $\mathrm{CO}$ insertion mechanism, which is very unstable in an $\mathrm{H}_{2}$ atmosphere and could easily be hydrogenated 
to alcohol products. Subsequently, the alcohol will be dehydrated to form a hydrocarbon intermediate or final product. These findings coincide with the reaction mechanism depicted in Scheme $1 \mathrm{~b}$. We therefore believe that the CO insertion mechanism is reasonable over iron-based catalysts for FTS chain propagation.

\subsection{The Effects of Alkenes and Alcohols on FTS Product Distribution}

The influence of 1-alkenes with different chain lengths $\left(C_{2}, C_{3}, C_{6}\right.$ and $C_{8}$ alkenes $)$ on the normal FTS reaction was studied. Results show that the addition of $C_{n}$ alkene caused a large increase in hydrocarbon selectivity from $C_{n}$ (Figure 7). The maximum $\mathrm{C}_{\mathrm{n}}$ selectivity could be ascribed to the direct hydrogenation of the added alkene into its corresponding alkane. The plot for the product distribution presents a parallel shift from a $\mathrm{C}_{\mathrm{n}+1}$ hydrocarbon, while the chain growth probability $\alpha$ in Figure 7 presents no significant difference. This essentially indicates that the surface concentration of $C_{n}$ intermediate was remarkably increased and served as a chain initiator in the FTS reaction. These results coincide with the mechanism routes discussed in previous sections.

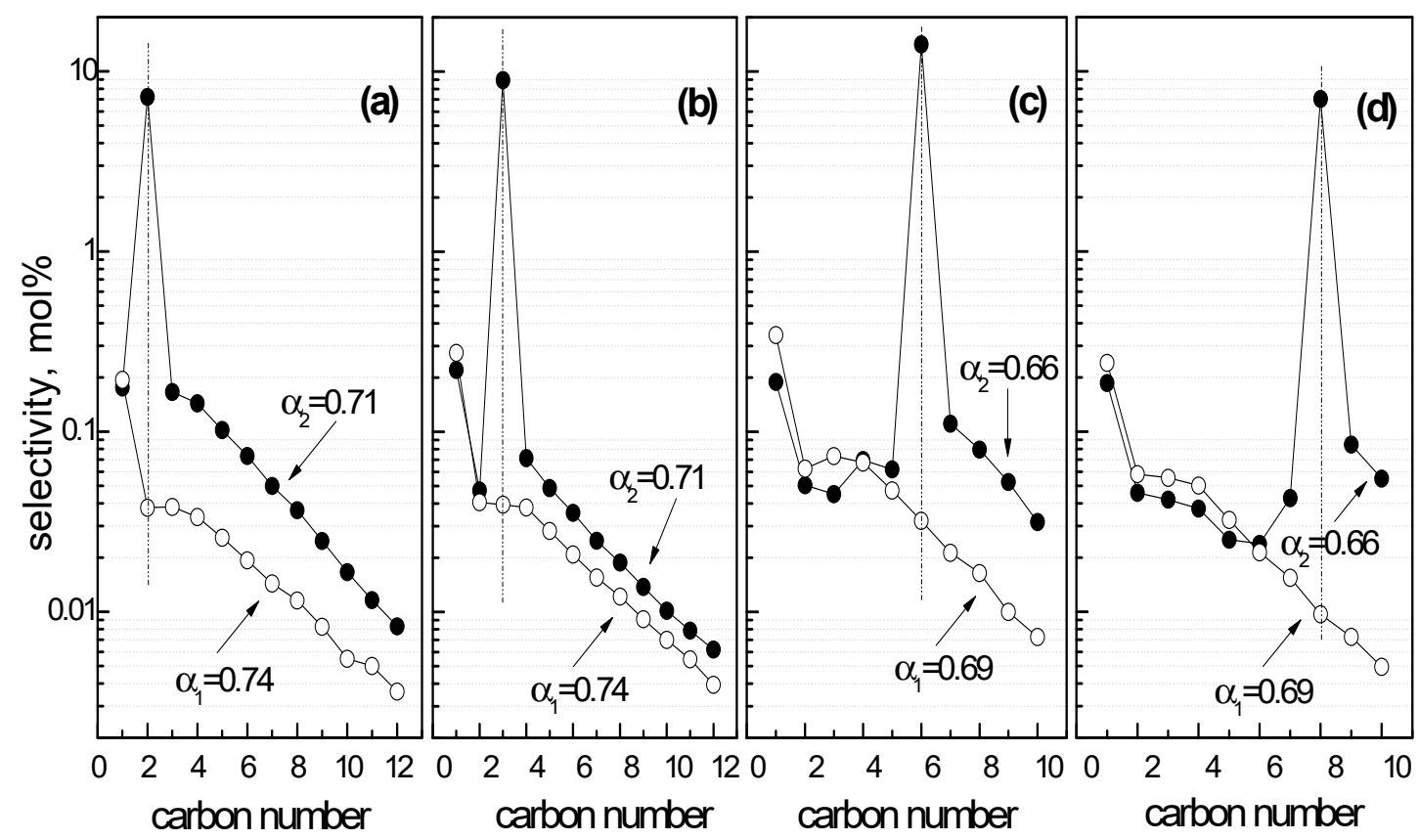

Figure 7. The effects of 1-alkene addition on FTS product distribution. (a) $\mathrm{C}_{2} \mathrm{H}_{4}$ addition ( $\mathrm{T}=533 \mathrm{~K}, p=1.0 \mathrm{Mpa}$, $\left.\mathrm{H}_{2} / \mathrm{CO}=8, \mathrm{H}_{2} / \mathrm{C}_{2} \mathrm{H}_{4}=4\right)$. (b) $\mathrm{C}_{3} \mathrm{H}_{6}$ addition $\left(\mathrm{T}=533 \mathrm{~K}, p=0.8 \mathrm{Mpa}, \mathrm{H}_{2} / \mathrm{CO}=12, \mathrm{H}_{2} / \mathrm{C}_{3} \mathrm{H}_{6}=5.6\right.$ ). (c) $\mathrm{C}_{6} \mathrm{H}_{12}$ addition $\left(\mathrm{T}=533 \mathrm{~K}, p=0.8 \mathrm{Mpa}, \mathrm{H}_{2} / \mathrm{CO}=5.4, \mathrm{H}_{2} / \mathrm{C}_{6} \mathrm{H}_{12}=2.6\right)$. (d) $\mathrm{C}_{8} \mathrm{H}_{16}$ addition $\left(\mathrm{T}=533 \mathrm{~K}, p=0.8 \mathrm{Mpa}, \mathrm{H}_{2} / \mathrm{CO}=5.4\right.$, $\left.\mathrm{H}_{2} / \mathrm{C}_{8} \mathrm{H}_{16}=5.1\right)$. (-•-) and (-O-) are the total hydrocarbon distributions with and without alkene addition, respectively.

The addition of $\mathrm{C}_{1}-\mathrm{C}_{3}$ alcohol only slightly affected the FTS product distribution (Figure 8). This phenomenon has also been confirmed by numerous alcohol co-feeding studies in published papers. Together with the low selectivity of alcohol products (especially the high-carbon-number alcohols) in the FTS process, few of the studies suggested that the secondary reaction of alcohol would be related to the deviation of ASF distribution. However, here we found that heavier alcohol addition (such as $\mathrm{C}_{5}$ and $\mathrm{C}_{6}$ alcohol) resulted in a significant parallel shift in hydrocarbon selectivity from $C_{n}$, without significantly affecting the value of the chain growth probability (Figure 9). Both parallel shifts presented in alkene and alcohol experiments here are very similar. 

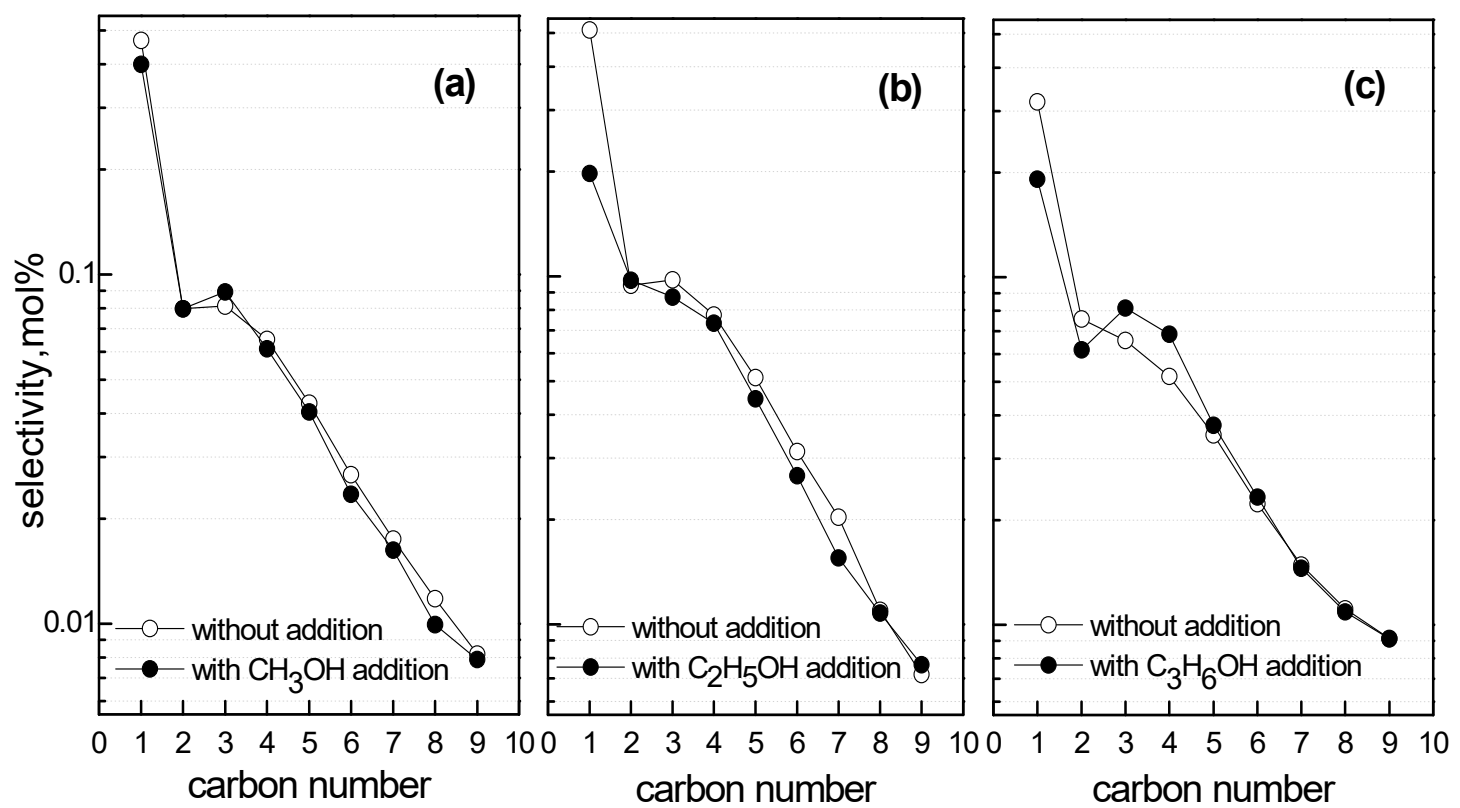

Figure 8. The effect of $\mathrm{C}_{1}-\mathrm{C}_{3}$ alcohol addition on the total hydrocarbon distribution in the FTS process. Reaction condition: $\mathrm{T}=533 \mathrm{~K}, p=0.8 \mathrm{Mpa}, \mathrm{H}_{2} / \mathrm{CO}=8$, and $(\mathbf{a}-\mathbf{c})$ with $\mathrm{CH}_{3} \mathrm{OH}=0.5 \mathrm{~mL} / \mathrm{h}, \mathrm{C}_{2} \mathrm{H}_{5} \mathrm{OH}=0.7 \mathrm{~mL} / \mathrm{h}$ and $\mathrm{C}_{3} \mathrm{H}_{7} \mathrm{OH}=1.0 \mathrm{~mL} / \mathrm{h}$, respectively.
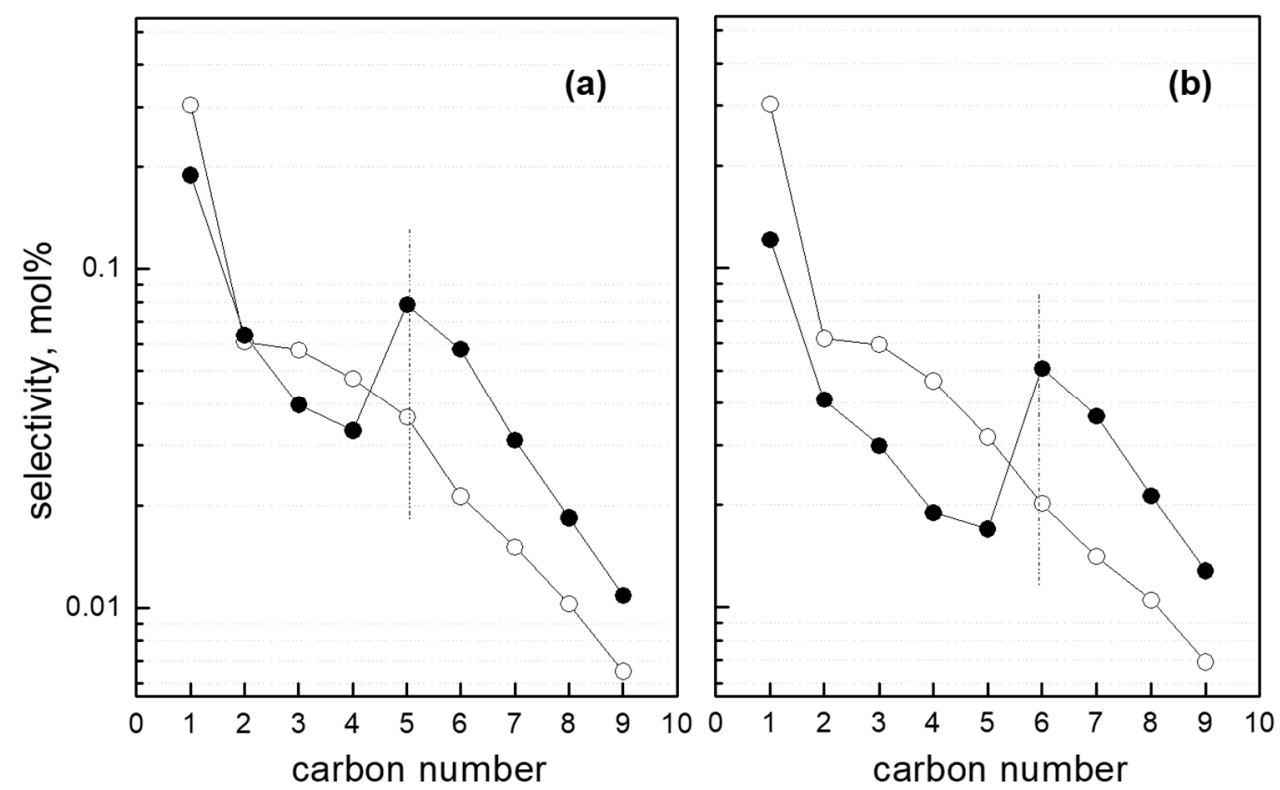

Figure 9. The effect of $C_{5}$ and $C_{6}$ alcohol addition on FTS product distribution. Reaction condition: $\mathrm{T}=533 \mathrm{~K}, p=0.8 \mathrm{Mpa}, \mathrm{H}_{2} / \mathrm{CO}=8$, and $(\mathbf{a}, \mathbf{b})$ with $\mathrm{C}_{5} \mathrm{H}_{11} \mathrm{OH}=1.0 \mathrm{~mL} / \mathrm{h}$ and $\mathrm{C}_{6} \mathrm{H}_{13} \mathrm{OH}=1.5 \mathrm{~mL} / \mathrm{h}$,

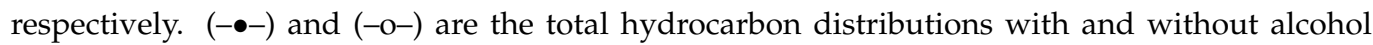
addition, respectively.

The above sections show that alkenes and oxygenates (such as aldehydes and alcohols) are very reactive over the iron-based catalyst. They seem to be very similar to the indigenous intermediate species and have similar chain growth factors when they are activated and incorporated into the chain growth reaction. These activated species serve mainly as chain initiators. Essentially, the effects on the total product distribution are simultaneously controlled by the surface carbide mechanism and the $\mathrm{CO}$ insertion mechanism, as discussed in previous sections. 
Many researchers have developed kinetic models by considering the secondary chain growth of alkenes to account for the FTS product distributions [21,25,30,57], but essentially only one type of these mechanisms was considered in the group of elementary steps. The assumption of alkene readsorption in these models could successfully predict the decrease of the alkene-to-alkane ratio with chain length. However, they were still not good enough in predicting the deviation in the actual FTS product spectrum from an ideal ASF distribution. Gao et al. [58] in our group also confirmed that the suppression of the secondary reaction of alkenes by polar solvent polyethylene glycol addition has not obviously reduced the deviation of the total hydrocarbon distribution from the theoretical ASF distribution, which still presented a two- $\alpha$ phenomenon. Together with the experimental results in this paper, we believe that kinetic modeling for FTS product distribution would be better if it included both the surface carbide mechanism and the $\mathrm{CO}$ insertion mechanism simultaneously. The reaction behavior of the added alkenes and oxygenates reflects the possible elementary steps of the two mechanisms. We could further hypothesize that the oxygen-involved intermediates with higher carbon numbers will have longer residence times in the catalyst pores and therefore enhance their chances of undergoing dehydration reactions for hydrocarbon intermediate formation and their repeated $\mathrm{CO}$ insertion. If so, the $\mathrm{CO}$ insertion mechanism may be more responsible for the positive deviation in FTS product distribution.

\section{Conclusions}

Both alkenes and oxygenates could be activated and converted to hydrocarbon intermediates, which then undergo $\mathrm{CH}_{x}$ or/and $\mathrm{CO}$ insertion for chain growth in the experimental investigation by aldehyde, alcohol and alkene addition. The experimental results obviously present a parallel shift in product distribution as compared with the normal FTS process. It can be inferred that the intermediates formed are very similar to the indigenous species produced on the surface of the catalysts and serve as a chain initiator in the chain growth. The experimental results evidence two parallel chain propagation pathways over a reduced iron-based catalyst: the surface carbide mechanism and the $\mathrm{CO}$ insertion mechanism with $\mathrm{CH}_{x}$ and $\mathrm{CO}$ as monomers, respectively.

The kinetic expression of FTS product distribution could be suggested to not only consider the theory of the secondary reaction of alkenes by the carbide mechanism. The reaction behavior of alkenes and their effects on product distribution are due to the joint action of the two mechanisms. Moreover, the high selectivity of the 2-alkene and the lack of aldehyde products in the real FTS process could be attributed to the instability of 1-alkene and aldehyde in an $\mathrm{H}_{2}$ atmosphere. These mechanism routes are very useful in FTS kinetic modeling and the explanation of the non-ASF product distribution.

Author Contributions: Conceptualization, methodology, validation, data analysis and original draft preparation: L.Z.; laboratory supervision and investigation: J.G. and X.H.; conceptualization, review and editing: Y.Y. and Y.L. All authors have read and agreed to the published version of the manuscript.

Funding: This research received no external funding.

Institutional Review Board Statement: The study was not conducted involving humans or animals, thus, ethical review and approval were waived for this study.

Acknowledgments: The authors are grateful to Synfuels China Technology Co., Ltd. for the experimental and technical support.

Conflicts of Interest: The authors declare no conflict of interest.

\section{References}

1. Davis, B.H. Overview of reactors for liquid phase Fischer-Tropsch synthesis. Catal. Today 2002, 71, 249-300. [CrossRef]

2. Yang, Y.; Xu, J.; Liu, Z.; Guo, Q.; Ye, M.; Wang, G.; Gao, J.; Wang, J.; Shu, Z.; Ge, W.; et al. Progress in coal chemical technologies of China. Rev. Chem. Eng. 2019, 36, 21-66. [CrossRef]

3. Biloen, P.; Helle, J.N.; Sachtler, W.M.H. Incorporation of surface carbon into hydrocarbons during Fischer-Tropsch synthesis: Mechanistic implications. J. Catal. 1979, 58, 95-107. [CrossRef] 
4. Pichler, H. Twenty-five Years of Synthesis of Gasoline by Catalytic Conversion of Carbon Monoxide and Hydrogen. Adv. Catal. 1952, 4, 271-341. [CrossRef]

5. Kummer, J.T.; Emmett, P.H. Fischer-Tropsch Synthesis Mechanism Studies. The Addition of Radioactive Alcohols to the Synthesis Gas. J. Am. Chem. Soc. 1953, 75, 5177-5183. [CrossRef]

6. Kollár, M.; De Stefanis, A.; Solt, H.E.; Mihályi, M.R.; Valyon, J.; Tomlinson, A.A. The mechanism of the Fischer-Tropsch reaction over supported cobalt catalysts. J. Mol. Catal. A Chem. 2010, 333, 37-45. [CrossRef]

7. Inderwildi, O.R.; Jenkins, S.J.; King, D.A. Mechanistic Studies of Hydrocarbon Combustion and Synthesis on Noble Metals. Angew. Chem. Int. Ed. 2008, 47, 5253-5255. [CrossRef] [PubMed]

8. Shetty, S.; Jansen, A.P.J.; van Santen, R.A. Direct versus Hydrogen-Assisted CO Dissociation. J. Am. Chem. Soc. 2009, 131, 12874-12875. [CrossRef] [PubMed]

9. Deng, L.-J.; Huo, C.-F.; Liu, X.-W.; Zhao, X.-H.; Li, Y.-W.; Wang, J.; Jiao, H. Density Functional Theory Study on Surface CxHy Formation from CO Activation on Fe3C(100). J. Phys. Chem. C 2010, 114, 21585-21592. [CrossRef]

10. Ojeda, M.; Nabar, R.; Nilekar, A.U.; Ishikawa, A.; Mavrikakis, M.; Iglesia, E. CO activation pathways and the mechanism of Fischer-Tropsch synthesis. J. Catal. 2010, 272, 287-297. [CrossRef]

11. Zhou, L.-P.; Hao, X.; Gao, J.-H.; Yang, Y.; Wu, B.-S.; Xu, J.; Xu, Y.-Y.; Li, Y.-W. Studies and Discriminations of the Kinetic Models for the Iron-Based Fischer-Tropsch Catalytic Reaction in a Recycle Slurry Reactor. Energy Fuels 2011, 25, 52-59. [CrossRef]

12. Brady, R.C.; Pettit, R. Reactions of diazomethane on transition-metal surfaces and their relationship to the mechanism of the Fischer-Tropsch reaction. J. Am. Chem. Soc. 1980, 102, 6181-6182. [CrossRef]

13. Hussain, S.T. Addition of 2-Percent Ethene, Propene and Acetylene in the Co-Hydrogenation Experiment for the Determination of Chain Growth Intermediate in the Fisher Tropsch Synthesis on Ru Alumina-Supported Catalyst. J. Chem. Soc. Pak. 1993, 15, 97-99.

14. Quyoum, R.; Berdini, V.; Turner, M.L.; Long, H.C.; Maitlis, P.M. Mechanistic Studies of Methylene Chain Propagation in the Fischer-Tropsch Synthesis. J. Catal. 1998, 173, 355-365. [CrossRef]

15. Bell, A.T. Catalytic Synthesis of Hydrocarbons over Group VIII Metals. A Discussion of the Reaction Mechanism. Catal. Rev. 1981, 23, 203-232. [CrossRef]

16. Eidus, Y.T. The mechanism of the Fischer-Tropsch reaction and the initiated hydropolymerisation of alkenes, from radiochemical and kinetic data. Russ. Chem. Rev. 1967, 36, 338. [CrossRef]

17. Botes, F.G.; Breman, B.B. Development and Testing of a New Macro Kinetic Expression for the Iron-Based Low-Temperature Fischer-Tropsch Reaction. Ind. Eng. Chem. Res. 2006, 45, 7415-7426. [CrossRef]

18. Van Der Laan, G.P.; Beenackers, A.A. Intrinsic kinetics of the gas-solid Fischer-Tropsch and water gas shift reactions over a precipitated iron catalyst. Appl. Catal. A 2000, 193, 39-53. [CrossRef]

19. van Steen, E.; Schulz, H. Polymerisation kinetics of the Fischer-Tropsch CO hydrogenation using iron and cobalt based catalysts. Appl. Catal. A 1999, 186, 309-320. [CrossRef]

20. Fernandes, F.A.N. Polymerization Kinetics of Fischer-Tropsch Reaction on Iron Based Catalysts and Product Grade Optimization. Chem. Eng. Technol. 2005, 28, 930-938. [CrossRef]

21. Van Der Laan, G.P.; Beenackers, A.A.C.M. Hydrocarbon Selectivity Model for the Gas-Solid Fischer-Tropsch Synthesis on Precipitated Iron Catalysts. Ind. Eng. Chem. Res. 1999, 38, 1277-1290. [CrossRef]

22. Blyholder, G.; Neff, L.D. Infrared study of the interaction of carbon monoxide and hydrogen on silica-supported iron. J. Phys. Chem. 1962, 66, 1664-1667. [CrossRef]

23. Henrici-Olivé, G.; Olivé, S. The Fischer-Tropsch Synthesis: Molecular Weight Distribution of Primary Products and Reaction Mechanism. Angew. Chem. Int. Ed. 1976, 15, 136-141. [CrossRef]

24. Huff, G.A.; Satterfield, C.N. Evidence for two chain growth probabilities on iron catalysts in the Fischer-Tropsch synthesis. J. Catal. 1984, 85, 370-379. [CrossRef]

25. Iglesia, E.; Reyes, S.C.; Madon, R.J. Transport-Enhanced Alpha-Olefin Readsorption Pathways in Ru-Catalyzed Hydrocarbon Synthesis. J. Catal. 1991, 129, 238-256. [CrossRef]

26. Liu, X.; Hamasaki, A.; Honma, T.; Tokunaga, M. Anti-ASF distribution in Fischer-Tropsch synthesis over unsupported cobalt catalysts in a batch slurry phase reactor. Catal. Today 2011, 175, 494-503. [CrossRef]

27. Bukur, D.; Mukesh, D.; Patel, S.A. Promoter effects on precipitated iron catalysts for Fischer-Tropsch synthesis. Ind. Eng. Chem. Res. 1990, 29, 194-204. [CrossRef]

28. Patzlaff, J.; Liu, Y.; Graffmann, C.; Gaube, J. Studies on product distributions of iron and cobalt catalyzed Fischer-Tropsch synthesis. Appl. Catal. A 1999, 186, 109-119. [CrossRef]

29. Kuipers, E.; Scheper, C.; Wilson, J.; Vinkenburg, I.; Oosterbeek, H. Non-ASF Product Distributions Due to Secondary Reactions during Fischer-Tropsch Synthesis. J. Catal. 1996, 158, 288-300. [CrossRef]

30. Schulz, H.; Claeys, M. Kinetic modelling of Fischer-Tropsch product distributions. Appl. Catal. A 1999, 186, 91-107. [CrossRef]

31. Kuipers, E.; Vinkenburg, I.; Oosterbeek, H. Chain Length Dependence of $\alpha$-Olefin Readsorption in Fischer-Tropsch Synthesis. J. Catal. 1995, 152, 137-146. [CrossRef]

32. Koenig, L.; Gaube, J. Fischer-Tropsch synthesis-Recent studies and developments. Chem. Inf. 1983, 14, 14-22. [CrossRef]

33. Tau, L.-M.; Dabbagh, H.; Bao, S.; Davis, B.H. Fischer-Tropsch synthesis. Evidence for two chain growth mechanisms. Catal. Lett. 1991, 7, 127-140. [CrossRef] 
34. Hall, W.K.; Kokes, R.J.; Emmett, P.H. Mechanism Studies of the Fischer-Tropsch Synthesis: The Incorporation of Radioactive Ethylene, Propionaldehyde and Propanol. J. Am. Chem. Soc. 1960, 82, 1027-1037. [CrossRef]

35. Snel, R.; Espinoza, R.L. Secondary reactions of primary products of the Fischer-Tropsch synthesis. 1. The Role of Ethene. J. Mol. Catal. 1987, 43, 237-247. [CrossRef]

36. Snel, R.; Espinoza, R.L. Secondary reactions of primary products of the Fischer-Tropsch synthesis. 2. The Role of Propene. J. Mol. Catal. 1989, 54, 103-117. [CrossRef]

37. Snel, R.; Espinoza, R.L. Secondary reactions of primary products of the Fischer-Tropsch synthesis. 3. The Role of Butene. J. Mol. Catal. 1989, 54, 119-130. [CrossRef]

38. Adesina, A.; Hudgins, R.; Silveston, P. Effect of ethene addition during the Fischer-Tropsch reaction. Appl. Catal. 1990, 62, 295-308. [CrossRef]

39. Jordan, D.S.; Bell, A.T. The influence of propylene on CO hydrogenation over silica-supported ruthenium. J. Catal. 1987, 107, 338-350. [CrossRef]

40. Hanlon, R.T.; Satterfield, C.N. Reactions of selected 1-olefins and ethanol added during the Fischer-Tropsch synthesis. Energy Fuels 1988, 2, 196-204. [CrossRef]

41. Tau, L.-M.; Dabbagh, H.A.; Chawla, B.; Davis, B.H. Fischer-Tropsch synthesis with an iron catalyst: Incorporation of ethene into higher carbon number alkanes. Catal. Lett. 1991, 7, 141-149. [CrossRef]

42. Shi, B.; Davis, B.H. Fischer-Tropsch Synthesis: Evidence for Chain Initiation by Ethene and Ethanol for an Iron Catalyst. Top. Catal. 2003, 26, 157-161. [CrossRef]

43. Fujimoto, K.; Fan, L.; Yoshii, K. New controlling method for product distribution in Fischer-Tropsch synthesis reaction. Top. Catal. 1995, 2, 259-266. [CrossRef]

44. Shi, B.; Jacobs, G.; Sparks, D.; Davis, B.H. Fischer-Tropsch synthesis: 14C labeled 1-alkene conversion using supercritical conditions with $\mathrm{Co} / \mathrm{A}_{2} \mathrm{O}_{3}$. Fuel 2005, 84, 1093-1098. [CrossRef]

45. Satterfield, C.N.; Huff, G.A.; Summerhayes, R. Olefin addition in Fischer-Tropsch synthesis on an iron catalyst. J. Catal. 1983, 80, 486-490. [CrossRef]

46. Balakos, M.; Chuang, S. Transient Response of Propionaldehyde Formation During CO/ $\mathrm{H}_{2} / \mathrm{C}_{2} \mathrm{H}_{4}$ Reaction on $\mathrm{Rh} / \mathrm{SiO} 2$. J. Catal. 1995, 151, 253-265. [CrossRef]

47. Tau, L.M.; Dabbagh, H.A.; Davis, B.H. Fischer-Tropsch synthesis: Comparison of carbon-14 distributions when labeled alcohol is added to the synthesis gas. Energy Fuels 1991, 5, 174-179. [CrossRef]

48. Tau, L.-M.; Dabbagh, H.A.; Halasz, J.; Davis, B.H. Fischer-Tropsch synthesis: Incorporation of 14C-labeled normal and isoalcohols. J. Mol. Catal. 1992, 71, 37-55. [CrossRef]

49. Gnanamani, M.K.; Keogh, R.A.; Shafer, W.D.; Shi, B.; Davis, B.H. Fischer-Tropsch synthesis: Deuterium labeled ethanol tracer studies on iron catalysts. Appl. Catal. A 2010, 385, 46-51. [CrossRef]

50. Yang, Y.; Xiang, H.; Zhang, R.; Zhong, B.; Li, Y. A highly active and stable Fe-Mn catalyst for slurry Fischer-Tropsch synthesis. Catal. Today 2005, 106, 170-175. [CrossRef]

51. Shi, B.; O'Brien, R.J.; Bao, S.; Davis, B.H. Mechanism of the Isomerization of 1-Alkene during Iron-Catalyzed Fischer-Tropsch Synthesis. J. Catal. 2001, 199, 202-208. [CrossRef]

52. Cramer, R. Olefin Coordination Compounds of Rhodium. III. The Mechanism of Olefin Isomerization. J. Am. Chem. Soc. 1966, 88, 2272-2282. [CrossRef]

53. Efstathiou, A.; Chafik, T.; Bianchi, D.; Bennett, C. A Transient Kinetic Study of the Co/ $\mathrm{H}_{2} \operatorname{Reaction}$ on $\mathrm{Rh} / \mathrm{Al}_{2} \mathrm{O}_{3} \mathrm{Using}$ FTIR and Mass Spectroscopy. J. Catal. 1994, 148, 224-239. [CrossRef]

54. Breejen, J.P.D.; Radstake, P.B.; Bezemer, G.L.; Bitter, J.H.; Frøseth, V.; Holmen, A.; De Jong, K.P. On the Origin of the Cobalt Particle Size Effects in Fischer-Tropsch Catalysis. J. Am. Chem. Soc. 2009, 131, 7197-7203. [CrossRef] [PubMed]

55. Curtis, V.; Nicolaides, C.; Coville, N.; Hildebrandt, D.; Glasser, D. The effect of sulfur on supported cobalt Fischer-Tropsch catalysts. Catal. Today 1999, 49, 33-40. [CrossRef]

56. Cornils, B.; Herrmann, W.A.; Rasch, M. Otto Roelen, Pioneer in Industrial Homogeneous Catalysis. Angew. Chem. Int. Ed. 1994, 33, 2144-2163. [CrossRef]

57. Wang, Y.-N.; Ma, W.-P.; Lu, Y.-J.; Yang, J.; Xu, Y.-Y.; Xiang, H.-W.; Li, Y.-W.; Zhao, Y.-L.; Zhang, B.-J. Kinetics modelling of Fischer-Tropsch synthesis over an industrial Fe-Cu-K catalyst. Fuel 2003, 82, 195-213. [CrossRef]

58. Gao, J.; Wu, B.; Zhou, L.; Yang, Y.; Hao, X.; Xu, J.; Xu, Y.; Cao, L.; Li, Y. Effective control of $\alpha$-olefin selectivity during FischerTropsch synthesis over polyethylene-glycol enwrapped porous catalyst. Catal. Commun. 2011, 12, 1466-1470. [CrossRef] 